\title{
ANTITRUST, LAW \& ECONOMICS, AND POLITICS
}

\author{
John J. GibBons*
}

In his article, Antitrust, Law E Economics, and the Courts, Professor Louis Kaplow poses three questions. First, he asks whether there has been a significant increase in the judiciary's use of economic analyses. Second, he questions whether economists, or legal scholars trained in the discipline of economics, have changed what they had previously been saying about economic issues in antitrust cases. Finally, Professor Kaplow inquires whether the recent changes made by the Supreme Court in antitrust law reflect the Court's adoption of the economic analysis proposed by the Chicago School of Law and Economics or whether the Court has simply recast antitrust doctrine to bring it more in congruence with the views of the currently dominant political party.

Professor Kaplow answers the questions he poses as follows: (1) Economic analysis in antitrust was around long before then Professors, now Judges, Bork, Posner, and Easterbrook, who are the leading spokesmen of the Chicago School, wrote a word on the subject; (2) the version of economic theory that these scholars urge as the only true gospel is not regarded as holy writ by many economists who are equally well respected; moreover, the assumption that the sole purpose of the antitrust laws is the production of efficiency is not borne out either by the text of the antitrust laws or by their legislative history; (3) the recent changes in the Supreme Court's antitrust doctrine do not reflect either an increased awareness of economic issues or a wholesale adoption of the Chicago School's economic efficiency philosophy.

Professor Kaplow's answers to the questions he poses appear to be correct. His evidence and arguments in support of each of his conclusions are persuasive. Moreover, he is right on target when he says that we are currently witnessing a political movement, rather than the development in the judiciary of any new economic sophistication. Even if one could attribute the recent changes in antitrust law to a wholesale adoption of Chicago-style economics, the movement still would be political. The agenda of the Chicago School of economics is a political agenda, just as Adam Smith's attack on mercantilism was a political attack.

All those who participated in the symposium at which this article was first presented did so because each in varying degrees believes in the utility of the academic disciplines loosely gathered together in the economics departments

Copyright $(1988$ by Law and Contemporary Problems

- Judge, United States Court of Appeals for the Third Circuit. 
of our universities. Just as historians by rigorous scrutiny of the past ascertain why wars were caused or avoided, and thereby suggest how to avoid the same errors in the future, so, too, economists, by observation and measurement, determine how wealth was and is accumulated and distributed. Moreover, a study of economics can predict, with a sufficient degree of accuracy, what will be the likely outcomes in wealth formation and distribution of one course of action, public or private, compared with another. Thus, to characterize the agenda of the Chicago School of economics as political is not to denigrate the desirability of increased economic sophistication among decisionmakers.

The point is different and more fundamental. Economic measurements, economic predictions, and regression analysis are useful tools for making choices. The selection of efficiency, which some of the Chicagoans define as wealth maximization, as the sole object of antitrust is a political choice, however, and political choices always have moral dimensions.

The Chicago School regards price theory to be as inexorable in operation as Newton's laws. As a consequence, they contend that the market will inevitably produce efficiency and wealth enhancement. Only those vertical restraints that are efficiency enhancing, and therefore consumer protecting, will survive in the marketplace. Predatory pricing is inconsistent with price theory, and therefore does not exist. Because the only purpose of antitrust laws is efficiency, much of what has traditionally concerned antitrust lawyers is irrelevant, and the courts should exclude from the coverage of the statutes almost everything except naked or horizontal price fixing. The Chicago School excepts naked horizontal price fixing from its general condemnation of antitrust law, not because the market will fail to eventually catch up with these rascals, but because this is the one instance in which enforcement will act to correct a breakdown in competitive conditions faster than will the inexorable operation of the market. This summary is, perhaps, an oversimplification of the Chicago School's position, but good enough for purposes of discussion.

Professor Kaplow points out that this agenda for the formation of legal rules that largely eliminate antitrust enforcement rests for its validity on several assumptions. The first assumption is that the Chicago School's price theory of the manner in which markets function in the real world is so clearly correct that it should be acted upon by the courts to the exclusion of any competing theories about how markets function. The second is that those statutes commonly identified as antitrust laws have no purpose other than the production of efficiency.

Of course, if price theory is as inexorable as Newton's laws, my point about moral ramifications is irrelevant. Sooner or later the market will catch up and swallow any choice that happens to be inconsistent with the inevitable triumph of market forces; the stronger will overcome the weaker. 
Abstractions like the Catholic Bishops' statement about distributive justice, ${ }^{1}$ therefore, can be dismissed out of hand when compared to the realities of price theory because people are motivated by economics, not morals, and thus always act consistently with price theory. If they do not, they are making a mistake, and will be ground up in the efficient progress of the market while total output and wealth increase.

To give the Chicagoans their due, none of them claim that one can empirically demonstrate price theory in the way one can demonstrate gravitation. But they do say that price theory is a sufficiently reliable indicator of human conduct in the marketplace and that we should be guided by it in formulating legal rules. Now allow a skeptic to suggest that price theory is not quite that reliable. An example will illustrate this point. One fundamental of price theory is that the sellers of goods and services, acting always in selfinterest, will always demand the highest price that the market will permit. There is a market for legal services; the intellectual, analytical, verbal, and oral skills of first-class lawyering. If price theory is really inexorable, the most intelligent lawyers should conform their conduct to it. However, not all of them do. Judge Easterbrook, for example, who is very knowledgeable about the market price for legal services and also a very talented lawyer, has chosen to sell his services to the United States at a price that is much lower than the market price. He will explain, of course, that the ego satisfaction that comes from the opportunity to exercise judicial power in good causes, to advance one's views, and to hold a position of honor is a form of compensation, a "good" in the economic sense. And so it is. But here is where price theory, as distinguished from economics in the less theoretical sense, ceases to be entirely reliable in making decisions. The easy part of any decision involves what can be quantified in dollars and cents. The hard part is dealing with what cannot be quantified, human motivations such as altruism, concern for others, ego satisfaction, sexual desire, mechanisms, and ambition. The Chicagoans assert that because price theory does not permit predatory pricing, there exists no predatory pricing. I am skeptical about deductive reasoning which leads to the conclusion that something never happened because it could not happen. The Chicagoans' reasoning is analogous to the reasoning that the structure of a bumblebee is inconsistent with aerodynamic theory, and therefore bumblebees cannot fly. Bees fly, and the evidence tends to suggest that predatory pricing exists.

Once the inadequacy of price theory is appreciated, even as a complete description of human behavior (and economics is a behavioral science), we should begin to think about the risk of error in relying upon it in adopting legal rules. Even the Chicagoans make no claim that they can empirically demonstrate the social desirability of their proposed rules. They ask us to accept on faith the assumptions that they substitute for data where data are hard to obtain. Absent reliable data, how are decisions to be made, except by

1. National Conference of Catholic Bishops, Economic Justice for All: Catholic Social Teaching and the U.S. Economy (22d draft Nov. 1985). 
relying upon the collective intuition of the broadest group of decisionmakers? Why should judicial activism be substituted for legislative consensus? Are five Justices of the Supreme Court more likely to arrive at a better intuitive conclusion about the human situation than one hundred Senators or four hundred and thirty-five members of the House of Representatives?

Entirely apart from my skepticism about the completeness of price theory, I have serious process reservations about the Chicago School's political agenda. Voicing these process reservations, I part company, slightly, from Professor Kaplow in that I think the political agenda of the Chicago School has to some extent been adopted by the Supreme Court. Before addressing one case in which I see evidence of that adoption, I should acknowledge that many provisions of the antitrust laws are open-textured, none more so than section 1 of the Sherman Act. Such open-textured statutes are an invitation by Congress to the courts to pour meaning into them from time to time. As I once put it in an opinion, which the Supreme Court reversed on other grounds,

It is quite another question whether legislative history from 1914 , strong as it appears, should control the contemporary application of a statute laying down a fundamental national economic policy. This is especially true when the significance of the circumstances to which application is sought were perceived dimly, if at all, at the time of passage. The antitrust laws are of necessity statements of general principle. They must be given meaning in specific application on a case-by-case basis. It is impossible for a legislature to devise codes so all-encompassing as to predict every case to which the general principle should apply. So, too, with antitrust remedies. There is a danger in permitting the pronouncements of statesmen long deceased to control the contemporary meaning of statutes which are almost an economic constitution for our complex national economy. ${ }^{2}$

Thus, I do not quarrel with the Chicagoans in their desire to have the court reconsider some of the substantive antitrust rules it once laid down in light of more contemporary economic knowledge. ${ }^{3}$

It is one thing, however, to overrule a demonstrably erroneous substantive interpretation of an open-textured statute. It is quite another to attempt to repeal a statute by the judicial invention of procedural barriers to its enforcement. An example of what I think is the wrong approach is Monsanto $\mathrm{v}$. Spray-Rite Service Corp. ${ }^{4}$ In Monsanto, Assistant Attorney General Baxter took the occasion of a private antitrust suit by a terminated distributor to urge that the Court overrule the long-standing holding in Dr. Miles Medical Co. v. John D. Park $\mathcal{E}^{3}$ Sons $\mathrm{Co}^{5}{ }^{5}$ that the per se rule applied to vertical as well as horizontal price fixing. Had the Court done so, I would not have been disappointed. I have never seen much harm in retail price maintenance because when I practiced law my clients were mostly manufacturers of trademarked products,

2. NBO Indus. Treadway Co. v. Brunswick Corp., 523 F.2d 262, 278-79 (3d Cir. 1975), vacated sub nom. Brunswick Corp. v. Pueblo Bowl-O-Mat, Inc., 429 U.S. 477 (1977).

3. For example, I believe that the Court's decision in United States v. Arnold, Schwinn \& Co., 388 U.S. 365 (1967), was wrongly decided and I think the Court was correct in overruling Schwinn in Continental T.V., Inc. v. GTE Sylvania, Inc., 433 U.S. 36 (1977).

4. 465 U.S. 752 (1984).

5. 220 U.S. 373 (1911). 
not discount retailers. The Court, however, declined Mr. Baxter's invitation, undoubtedly because the recent signals from Congress, such as the repeal of a portion of the McGuire Act, ${ }^{6}$ indicated that an outright overruling of $\mathrm{Dr}$. Miles Medical Co. would be politically unacceptable. Moreover, the Court affirmed a judgment in favor of the terminated distributor. It took the occasion, however, to indicate to the lower courts a way to shut the door on such cases at the summary judgment stage by elevating the evidentiary standard for proof of concert of action. In Monsanto, distributor A complained to the manufacturer that distributor B was price cutting. The manufacturer then terminated distributor B. That evidence, the Court said, was insufficient to present a jury question as to whether the termination was the result of concert of action between distributor $\mathrm{A}$ and the manufacturer.

The issue of what evidence is legally sufficient to permit an inference of conspiracy is neither an economic nor an antitrust issue. Rather, it is a process issue, and the validity of the Monsanto Court's reasoning can be tested by the following hypothetical. Figuero Enterprises is a chemical manufacturer that distributes its product through independent distributors. The product is Colombian Cocaine. Distributor Angel calls Figuero and says that distributor Jesu is cutting price, stealing Angel's customers, and taking a free ride on his protection. Figuero says "I'm glad you told me." Figuero then calls his director of distributor relations, Louie the Lug, and explains that Jesu is causing disorder in the market. "I'll take care of it" says Louie, and he goes out on the street and breaks Jesu's legs. Unfortunately for Figuero, Angel, and Louie, the authorities have been tapping Figuero's telephone, and they indict Angel, Figuero, and Louie. At the trial, the government offers the wiretap of the conversation between Angel and Figuero to prove that Angel is a member of a conspiracy, and the wiretap of the conversation between Figuero and Louie against Angel, as a coconspirator's admission in the course of a furtherance of the conspiracy. The evidence is admitted and the jury convicts Angel.

Whether Angel's appeal comes before Justice Powell, Judge Easterbrook, or Judge Gibbons, the outcome will be a holding that there was sufficient evidence from which the jury could find beyond a reasonable doubt that Angel was a member of the conspiracy to discipline Jesu. Yet, it is clear that Figuero, like Monsanto, was always free to take unilateral action against a distributor to clean up the retail market. However, by calling the inferencedrawing issue in Monsanto an antitrust or economic issue while calling the

6. Consumer Goods Pricing Act of 1975, Pub. L. No. 94-145, § 3, 89 Stat. 801 (repealing paragraphs (2) through (5) of section 5(a) of the Federal Trade Commission Act of 1914, Pub. L. No. 203, $\$ 5,38$ Stat. 719). 
issue in United States $v$. Angel an evidence issue, the Court will feel free to reach different results. So much for equal justice under the law. ${ }^{7}$

What Judge Easterbrook suggests in his article The Limits of Antitrust ${ }^{8}$ is that the courts should resort to such door-closing devices more frequently. There is already case law to the effect that remote purchasers lack standing, ${ }^{9}$ that employees lack standing, ${ }^{10}$ and that lessors lack standing. ${ }^{11}$ Judge Easterbrook would add a rule that competitors lack standing. ${ }^{12}$ What would then be left of private antitrust enforcement would be suits by the first purchasers from participants in a horizontal price fixing conspiracy. I cannot personally recall such a suit that was not the result of an antecedent government investigation, probably because absent the pre-litigation subpoena power possessed by the government, such a horizontal conspiracy will never be discovered by its victims.

These door-closing devices in antitrust are all aimed at preventing, in private enforcement cases, the development of records in which competing versions of what already had and what would later happen in the market could be presented, subjected to adversarial scrutiny, and assessed by the factfinder. ${ }^{13}$ The Chicago School advocates acceptance of its devices with complete confidence that its theory is the only true gospel of economics, and that litigants ought, therefore, to be deprived of the opportunity to present

7. A more recent example of the Court's manipulation of the summary judgment standard set out in Rule $\mathbf{5 6}$ of the Federal Rules of Civil Procedure is the Court's decision in Matsushita Elec. Indus. Co. v. Zenith Radio Corp., 475 U.S. 574 (1986).

The practice of using procedural devices to achieve substantive outcomes is obviously not a new development. Nor is it one confined to cases presenting economic issues. In the Third Circuit, for example, there is a line of cases holding that for civil rights complaints, the pleading standards of Conley v. Gibson, 355 U.S. 41, $47-48$ (1957), do not govern, and complaints may be dismissed on the ground that they do not sufficiently plead evidentiary facts. See, e.g., Frazier v. Southeastern Pa. Transp. Auth., 85 F.2d 65, 67 (3d Cir. 1986); Rotolo v. Borough of Charleroi, 532 F.2d 920, 927 (3d Cir. 1976).

The line of cases stemming from Justice Black's opinion in Younger v. Harris, 401 U.S. 37 (1971), is another good example of the manipulation of procedural rules for the purpose of reducing the capacity of the federal courts for civil rights enforcement. Looking in a different direction is the Supreme Court's recent manipulation in Michigan v. Long, 463 U.S. 1032 (1968), of the long established rules dealing with ambiguous state court opinions granting relief on arguable federal grounds so as to cut back on civil rights enforcement in the state courts as well. Of course, the most useful procedural barrier device is the invention of standing rules.

8. Easterbrook, The Limits of Antitrust, 63 TEX. L. REv. 1 (1984).

9. See Illinois Brick Co. v. Illinois, 431 U.S. 720 (1977).

10. See Associated Gen. Contractors v. California State Council of Carpenters, 459 U.S. 519 (1983) (carpenters union, not person, injured by violation of antitrust laws). Compare Pitchford v. Pepi, Inc., 531 F.2d 92, 96-98 (3d Cir.), cert. denied, 426 U.S. 935 (1976) (antitrust plaintiff's corporate president lacked standing both as stockholder and officer), with International Ass'n of Heat and Frost Insulators \& Asbestos Workers v. United Contractors Ass'n, 483 F.2d 384 (3d Cir. 1973), modified, 494 F.2d 1353 (3d Cir. 1974) (both construction workers and their union representation had standing to bring antitrust action).

11. See Melrose Realty Co. v. Loew's, Inc. 234 F.2d 518 (3d Cir.), cert. denied, 352 U.S. 890 (1956).

12. See Easterbrook, supra note 8, at 35-37.

13. Prior to the Court's creation of procedural barriers, the Court benefited from reviewing antitrust cases that came to it after a full trial. See, e.g., United States v. United Shoe Mach. Corp., 391 U.S. 244, 245 (1968); Brown Shoe Co. v. United States, 370 U.S. 294 (1962); United States v. E.I. DuPont De Nemours \& Co., 351 U.S. 377,379 (1956). 
testimony tending to support conclusions other than those arrived at by deduction from the price theory. Like a latter day grand inquisitor, the Chicago School has very little tolerance for what it believes to be error.

This heavy assault upon private enforcement prompts the question why Congress provided for it in the first place. When it comes to public enforcement, the administration is free to swallow Chicago-style economic theory hook, line, and sinker and to act accordingly, not because it is certain that the Chicago School is right, but because the administration won the election and is in charge. The congressional decision to provide for private enforcement, however, was a determination that the market as well as the politicians would have input in enforcement decisions; that the availability of private enforcement would mean that no single economic theory or set of values would, by virtue of the political process, be permitted to exclude from consideration alternative theories and values. The dispersal of decisional responsibility that results from competition among competing theories and values is a safeguard against the harm that might occur from foolish management decisions. When judges, and particularly Supreme Court Justices, begin to invent procedural barriers to private enforcement-and that is what the talk of filters and presumptions and standing and strict proof of conspiracy is all about-they magnify the risk of error by barring from consideration any economic theory or any value except that which is currently fashionable among the five Justices in the majority.

The litigation process is not, by any means, a sure way of arriving at ultimate truth about past or future human behavior. Allowing the presentation of competing claims to be fully developed before a factfinder who at least aspires to the ideal of neutrally resolving those claims on the basis of the evidence presented, however, is more likely to arrive at ultimate truth more frequently than would be the case if all such claims were resolved by deductive reasoning from a price theory which is treated as incontestable truth.

Thus, I agree with Professor Kaplow that what we see in recent Supreme Court developments in antitrust law is not a movement to identify efficiency as the sole goal of antitrust law and not a movement to treat economic issues differently than they were treated in the past. What can be seen, if anything, is a political movement to make private enforcement more difficult, and thereby maximize the decisional responsibility of the political party that won the election. I differ from Professor Kaplow in that I see the Chicago School itself less as an economic, than as a political, movement. It is politically dedicated to the desirability of a totally unregulated market, to the exclusion of such quaint ideas as distributive justice.

The next area of the law to which the law and economics crowd will turn its attention probably will be labor law, which includes the common law of at-will employment, the National Labor Relations Act of $1947,{ }^{14}$ and Title VII of the

14. 29 U.S.C. $\$ \$ 151-69$ (1982). 
Civil Rights Act of $1964 . .^{15}$ Indeed, some statements of Clarence Pendleton sound very much like Chicago School economics. ${ }^{16}$ Labor law and economics may well be the next symposium.

16. Pendleton, Equality of Opportunity or Equality of Results?, 13 Hum. RTs. 19, 44 (1985). See also N.Y. Times, Mar. 28, 1985, § A, at 29, col. 1 . 